\title{
Cancer stem cell marker-positive tumour nests in intrahepatic cholangiocarcinoma are related to epithelial type CD1a-positive dendritic cell infiltration and to high Sox9 expression
}

Aya Utsunomiya ( $\nabla$ aya-sutou@med.id.yamagata-u.ac.jp )

Yamagata University https://orcid.org/0000-0003-4646-3273

Rintaro Ohe

Yamagata Daigaku

Takanobu Kabasawa

Yamagata Daigaku

Naing Ye Aung

Yamagata Daigaku

Yuka Urano

Yamagata Daigaku

Nobuyuki Tamazawa

Yamagata Daigaku

Takumi Kitaoka

Yamagata Daigaku

Kazushi Suzuki

Yamagata Daigaku

Ichiro Kawamura

Yamagata Daigaku

Wataru Kimura

Yamagata Daigaku

Mitsunori Yamakawa

Yamagata Daigaku

\section{Research}

Keywords: intrahepatic cholangiocarcinoma, cancer stem cell, immature dendritic cell, antitumor immunity, prognosis

Posted Date: June 18th, 2020

DOI: https://doi.org/10.21203/rs.3.rs-36086/v1

License: @ (i) This work is licensed under a Creative Commons Attribution 4.0 International License. Read Full License 


\section{Abstract \\ Background}

It is yet a mystery whether dendritic cells (DCs) contact cancer stem cells (CSCs) and uptake CSC antigens in intrahepatic cholangiocarcinoma (ICC). The aim of this study was to examine the histological relationship between tumour cells expressing CSC markers and DCs infiltrating ICC. In addition, clinicopathological factors, including progression-free survival (PFS) and overall survival (OS), were compared between cases with many and few CSC marker-positive cells.

\section{Materials and methods}

Resected tissue sections of 22 cases with ICC were used for immunostaining to detect DC infiltration into ICC tumour nests positive for CD1a, DC-SIGN, DEC205, DC-LAMP, and CD123 and to detect ICC tumour cells positive for CSC markers such as CD44v9, EpCAM, and Sox9. The relationship between the number of CSC marker-positive cells and ICC clinicopathological factors was examined by Kaplan-Meier method and univariate and multivariate analyses using the Cox proportional hazards model.

\section{Results}

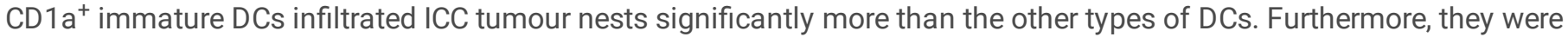
frequently localized within CD44v9- and EpCAM ${ }^{\text {high }}$ ICC tumour nests. According to Kaplan-Meier method, PFS and OS were longer in the Sox $9^{\text {high }}$ group than in the Sox ${ }^{\text {low }}$ group, and according to both univariate and multivariate analyses, Sox 9 expression was an independent factor.

\section{Conclusion}

The present study first demonstrated that CD $1 \mathrm{a}^{+}$immature DCs frequently infiltrated CD44v9- and EpCAM ${ }^{\text {high }}$ ICC tumour nests, suggesting the possibility of cell-to-cell contact between epithelial type immature DCs and CSCs in ICC. Furthermore, it was suggested that Sox9 expression in ICC may be a prognostic factor.

\section{Background}

Dendritic cells (DCs) are functionally classified into immature, mature, or activated cells(1). Immature DCs become mature or activated DCs by pathogens and inflammatory cytokines and can stimulate and activate T cells. In antitumour immunity, immature DCs infiltrate tumour tissues, and when they uptake tumour antigens, they migrate to the draining lymph nodes while maturing and activating to present tumour antigens to T cells. Antigen-specific T cells leave the lymph nodes and infiltrate the tumour again to exert antitumour immunity(2). Indeed, many carcinomas contain various levels of migrating immature DCs, mature/activated DCs, and plasmacytoid DCs(3), and it has been reported that frequent $C D 1 a^{+}$DCs also infiltrate intrahepatic cholangiocarcinoma (ICC) tissue(4).

Cholangiocarcinoma is a relatively rare malignant and lethal tumour derived from bile duct epithelium, and the morbidity is now increasing worldwide. This type of carcinoma is closely related to the tumour microenvironment and can be regulated by the interaction between cancer stem cells (CSCs)(5). CSCs are small cell populations of cancer cells capable of self-renewal and pluripotency and bring morphological and other types of diversity to tumours(6). CSCs also contribute to tumour initiation, malignant growth, and chemoresistance(7). Various markers expressed on CSCs include CD133(8), CD44(9), epithelial cell adhesion molecule (EpCAM), MOC31, CD326(10), aldehyde dehydrogenase 1(11), sex determining region Y-box2 (Sox2)(9), and Sox9(12). CD44 is a cell surface adhesion molecule that binds to extracellular matrix molecules, such as hyaluronic acid and osteopontin(13), and has ten subtypes(14). In particular, CD44 variant 9 (CD44v9) regulates the redox potential and suppresses 
the accumulation of reactive oxygen species in cells, thereby maintaining CSC survival(15). EpCAM is a cell surface marker for endodermal progenitor cells(16) and serves as an adhesion molecule between cells. Although EpCAM is involved in the control of cell proliferation, EpCAM-positive ICC cases have a poor prognosis(17). Sox9 is an endodermal transcription factor(16) that is involved in the maintenance of bile duct progenitor cells in the normal adult liver. However, Sox9-positive ICC has the potential to undergo metastasis, invasion, and epithelial-mesenchymal transition, resulting in poor prognosis(18).

Recent studies using CSCs as target cells for the treatment of cancers have been published(19), but it is yet mysterious whether DCs can recognize CSC antigens in human cancer tissues. Furthermore, information about the relationship between the frequency of CSC marker-expressing tumour cells and the survival of ICC patients is still limited. The aim of this study was to examine the histological relationship between tumour cells expressing CSC markers, such as CD44v9, EpCAM, and Sox9, and DCs infiltrating ICC. In addition, clinicopathological factors, including progression-free survival (PFS) and overall survival (OS), were compared between cases with many and fewer CSC marker-positive cells.

\section{Materials And Methods}

\section{Tissue samples}

Samples from twenty-two ICC cases that had been pathologically diagnosed at Yamagata University Hospital and Yonezawa Municipal Hospital from 2003 to 2018 were used. The diagnosis of ICC was made based on the WHO classification(20). One case of breast cancer and colon cancer was used as positive controls for the CSC markers CD44v9 and EpCAM (breast cancer) and Sox9 (colon cancer) in immunohistochemistry and reverse transcription-polymerase chain reaction (RT-PCR)(21-23). One tonsillar tissue with chronic tonsillitis was used as a positive control for DC markers in immunohistochemistry. All the excised tissues were fixed with $10 \%$ buffered neutral formalin at room temperature for 12 to $48 \mathrm{hrs}$ and embedded in paraffin. This study was approved by the Yamagata University School of Medicine Ethics Committee (H29-302).

\section{Immunohistochemistry}

Three $\mu \mathrm{m}$-thick tissue sections were prepared from paraffin-embedded blocks. Immunohistochemistry was performed as previously described(24). In brief, after deparaffinization, the endogenous peroxidase activity was stopped by immersion in methanol containing $0.3 \% \mathrm{H}_{2} \mathrm{O}_{2}$ at $4{ }^{\circ} \mathrm{C}$ for $30 \mathrm{~min}$. For antigen retrieval, an autoclave method $\left(2 \mathrm{~atm}, 121^{\circ} \mathrm{C}, 20 \mathrm{~min}\right)$ using citrate buffer (pH 6.0; LSI Medience, Tokyo, Japan), antigen activation solution (pH 9.0; Nichirei Bioscience, Tokyo, Japan), or proteinase K (Agilent Technologies, Tokyo, Japan) was used. After washing with $0.01 \mathrm{M}$ phosphate-buffered saline, $\mathrm{pH} 7.4$, the primary antibodies were incubated with the samples in a humid box at room temperature for $1 \mathrm{hr}$. Primary antibodies against CD1a (MTB1, mouse IgG1; Leica Biosystems, Nussloch, Germany), DC-SIGN (CD209) (polyclonal rabbit IgG; Santa Cruz Biotechnology, Dallas, TX), DEC205 (CD205) (LY, mouse IgG; Abcam plc, Cambridge, UK), DC-LAMP (CD208) (104.G4, mouse IgG1; Beckman Coulter, Brea, CA), CD123 (BR4MS, mouse IgG2b; Leica Biosystems), CD44v9 (RV3, rat IgG2a; Cosmo Bio, Tokyo, Japan), EpCAM (VU-1D9, mouse IgG1k; Abcam plc), and Sox9 (polyclonal rabbit; Chemicon, Tokyo, Japan) were used. A biotinlabelled anti-mouse IgG or anti-rabbit IgG antibody (Nichirei Biosciences) was used as the secondary antibody and was followed by streptavidin/AP (Agilent Technologies), an anti-mouse EnVision antibody (Agilent Technologies), or an anti-rabbit EnVision antibody (Agilent Technologies). Instead of a primary antibody, $0.01 \mathrm{M}$ phosphate-buffered saline, pH 7.4, Universal Negative Control-Mouse (N1698; Agilent Technologies), and Universal Negative Control-Rabbit (N1699; Agilent Technologies) were used as negative controls.

First, the number of positive cells for five different DC markers within tumour nests of ICC were counted. Ten tumour nests infiltrated by the higher number of DCs positive for each DC marker, such as CD1a, DC-SIGN, DEC205, DC-LAMP, and CD123, were photographed under a high-power field (HPF, 400x in magnification). The number of DCs infiltrating tumour nests was counted on the picture screen, and the ratio of tumour nests simultaneously occupying the screen was defined as the tumour nest occupancy rate (Supplemental Fig. 1a \& 1b). Finally, "the corrected DC number" was calculated as "the number of DCs within the tumour nest per HPF"/"tumour nest occupancy". 
Second, the percentage of CSC marker-positive tumour cells per total of tumour cells in a section was scored as follows: score 0, $0 \%$; score $1+, 1-25 \%$; score $2+, 26-50 \%$; and score $3+,>50 \%$. Furthermore, cases positive for CD $44 \mathrm{v} 9$ were divided into CD $44 \mathrm{v} 9^{+}$ group for scores $1+$ to $3+$ and $\mathrm{CD} 44 \mathrm{v} 9^{-}$group for score 0 , those positive for EpCAM were divided into EpCAM ${ }^{\text {high }}$ group for score $3+$ and EpCAM $^{\text {low }}$ group for scores 0 to $2+$, and those positive for Sox 9 were divided into the Sox $9^{\text {high }}$ group for score $3+$ and Soxglow group for scores 0 to $2+$.

Third, the number of each of the five types of DCs (CD1a, DC-SIGN, DEC205, DC-LAMP, and CD123) infiltrating the tumour nests

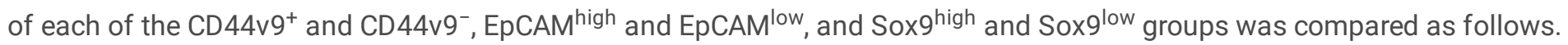
Serial sections were prepared from formalin-fixed and paraffin-embedded tissues, and a pair of sections among them were immunostained for the DC marker and the CSC marker. Tumour nests immunopositive for the CSC marker in one section were encircled by lines on the HPF photographs, and the same nests immunostained for the DC marker in another section were encircled by lines on HPF photographs. The numbers of DC marker-positive cells in the encircled tumour nests were counted, and the same method was used to calculate "the corrected DC number" (CD44v9 $9^{+}$group) (Supplemental Fig. 1c \& d). Haematoxylin and eosin staining of a serial section assisted in the calculation of "the corrected DC number" within the CSC marker-negative tumour nests (CD44v9- group). Similarly, in the cases of EpCAM and Sox9 immunostaining, both tumour nests exhibiting a score 3+ (EpCAM ${ }^{\text {high }}$ and Sox $9^{\text {high }}$ groups) and scores 0 to 2+ (EpCAM ${ }^{\text {low }}$ and Sox9 $9^{\text {low }}$ groups) were independently marked, and "the corrected DC number" within each tumour nest was calculated. One to 10 tumour nests infiltrated by a high number of DCs positive for each DC marker were evaluated. These counts and calculations were performed independently by two pathologists (U.A. and K.T.).

Finally, the correlation between the frequency of the expression of CSC markers on ICC tumour cells and PFS and OS was

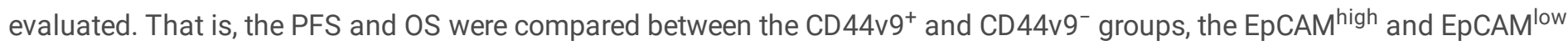
groups, and the Sox $9^{\text {high }}$ and Sox $9^{\text {low }}$ groups by the Kaplan-Meier method (log-rank test).

\section{Reverse transcription-polymerase chain reaction (RT-PCR)}

RT-PCR was performed using 4 cases with ICC and one case with breast cancer and colon cancer as positive controls, respectively, as previously described(25). mRNA was extracted and purified from paraffin-embedded tissues using WaxFree RNA (TrimGen, Sparks, MD). The following primer sequences were designed: 5'-GGCTTGGAAGAAGATAAAGACC-3' and 5'TGCTTGATGTCAGAGTAGAAGTTG-3' for human CD44v9 (52 bp), 5'-GCTGGCCGTAAACTGCTTTG-3' and 5'ACATTTGGCAGCCAGCTTTG-3' for human EpCAM (100 bp), 5'-GCTCTGGAGACTTCTGAACGA-3' and 5'CCGTTCTTCACCGACTTCCT-3' for human Sox9 (132 bp), and 5'-GCACCGTCAAGGCTGAGAAC-3' and 5'-

TGGTGAAGACGCCAGTGGA-3' for human glyceraldehyde-3-phosphate dehydrogenase (GAPDH, $138 \mathrm{bp}$ ) as internal controls. For EpCAM and Sox9, primers designed by PrimerBlast were used. As a negative control, a blank control during mRNA extraction and cDNA synthesis was used.

\section{Statistical analysis}

Statistical analyses were performed with JMP version 14 (SAS Institute, Tokyo, Japan) and Microsoft Excel 2013 (Microsoft, Redmond, WA). The Mann-Whitney U test was performed for comparison between the two groups. The Kaplan-Meier method (log-rank test) was used to compare PFS and OS. PFS was from the date of surgery to the date of recurrence on the image or the last observation date, and OS was the date of surgery to the date of death or last observation. Univariate or multivariate analysis was performed on the effect of clinicopathological factors on survival using the Cox proportional hazards model. In all tests, $P<$ 0.05 was determined to be significant.

\section{Results}

\section{Comparison of the number of DCs infiltrating the ICC tumour nests}

Page $4 / 16$ 
"The corrected DC number" within 10 tumour nests was measured in 22 cases with ICC. The numbers of positive DCs for CD1a, DC-SIGN (immature DCs), DEC205, DC-LAMP (mature DCs), and CD123 (plasmacytoid DC) were 4.89 $\pm 5.97,0.53 \pm 2.74,0.29 \pm$ $1.71,1.48 \pm 5.28$, and $0 \pm 0$, respectively (Fig. 1a-e). CD1a ${ }^{+}$immature DCs were the most abundant among any type of DCs infiltrating the tumour nests $(P<0.01)$ (Table 1$)$.

Table 1

The number of dendritic cells (DCs) infiltrating within tumor nests of intrahepatic cholangiocarcinoma (ICC)

\begin{tabular}{|lll|}
\hline Types of DCs & DC markers & The number of DCs infiltrating within ICC tumor nests (per 400x field of view) \\
\hline Immature DCs & CD1a & $4.89 \pm 5.97$ \\
\cline { 2 - 3 } & DC-SIGN & $0.53 \pm 2.74$ \\
\hline Mature/activated DCs & DEC205 & $0.29 \pm 1.71$ \\
\cline { 2 - 3 } & DC-LAMP & $1.48 \pm 5.28$ \\
\hline Plasmacytoid DCs & CD123 & $0 . \pm 0$. \\
\hline$* P<0.01$ & & \\
\hline
\end{tabular}

\section{Comparison of "the corrected DC number" infiltrating tumour nests of ICC between the CD44v9 ${ }^{+}$and $\mathrm{CD}_{4} 4 \mathrm{v9} 9^{-}$groups, the EpCAM ${ }^{\text {high }}$ and EpCAM ${ }^{\text {low }}$ groups, and the Sox $9^{\text {high }}$ and Soxglow groups}

Fourteen cases were included in the CD44v9 $9^{+}$group (score $1+, 7$ cases; $2+, 6$ cases; and $3+, 1$ case) and 8 cases were included in the CD44v9- group (score 0); 18 cases were included in the = EpCAM ${ }^{\text {high }}$ group (score $3+$ ) and 4 cases were included in the EpCAM $^{\text {low }}$ group (score 0, 2 cases; $1+, 1$ case; and 2+, 1 case); and 16 cases were included in the Sox $9^{\text {high }}$ group (score 3+) and 6 cases were included in the Sox ${ }^{\text {low }}$ group (score 0,2 cases; $1+, 0$ case; and $2+, 4$ cases) (Fig. 1f, g, \& $h$ ). The comparison of "the corrected DC number" infiltrating the tumour nests between the CD44v9+ and CD44v9 $9^{-}$groups, the EpCAM ${ }^{\text {high }}$ and EpCAM ${ }^{\text {low }}$ groups, and the Sox $9^{\text {high }}$ and Sox9low groups is shown in Table 2. The number of CD1a+ DCs was higher in the CD44v9 ${ }^{-}$group $(4.39 \pm 5.30)$ than in the $C D 44 v 9^{+}$group $(2.66 \pm 4.54)(P<0.01)$ and higher in the EpCAMhigh group $(5.52 \pm 7.64)$ than in the EpCAM $^{\text {low }}$ group $(2.50 \pm 3.80)(P<0.01)$, although there was no significant difference between the Soxghigh $(4.00 \pm 6.01)$ and Sox ${ }^{\text {low }}$ groups $(2.74 \pm 3.57)$. There were, however, no significant differences in the numbers of any DCs positive for DC-SIGN, DEC205, DC-LAMP, and CD123 between the CD44v9+ and CD44v9- groups, the EpCAM ${ }^{\text {high }}$ and EpCAM ${ }^{\text {low }}$ groups, and the Soxghigh and Sox ${ }^{\text {low }}$ groups. 
Table 2

Comparison of "the corrected dendritic cell number" infiltrating within tumor nests of intrahepatic cholangiocarcinoma between cancer stem cell (CSC) marker-high and -low groups

\begin{tabular}{|c|c|c|c|c|c|c|c|c|c|c|}
\hline \multicolumn{2}{|c|}{ Dendritic cells } & \multicolumn{3}{|l|}{ CD44v9 } & \multicolumn{3}{|c|}{ EрСAM } & \multicolumn{3}{|l|}{ Sox9 } \\
\hline Markers & Types & $\begin{array}{l}\text { Positive } \\
(n=14)\end{array}$ & $\begin{array}{l}\text { Negative } \\
(n=8)\end{array}$ & $\begin{array}{l}P \\
\text { value }\end{array}$ & $\begin{array}{l}\text { High } \\
(n= \\
18)\end{array}$ & $\begin{array}{l}\text { Low } \\
(n= \\
4)\end{array}$ & $\begin{array}{l}P \\
\text { value }\end{array}$ & $\begin{array}{l}\text { High } \\
(n= \\
16)\end{array}$ & $\begin{array}{l}\text { Low } \\
(n= \\
6)\end{array}$ & $\begin{array}{l}P \\
\text { value }\end{array}$ \\
\hline CD1a & Immature & $\begin{array}{l}2.66 \pm \\
4.54\end{array}$ & $\begin{array}{l}4.39 \pm \\
5.30\end{array}$ & $\begin{array}{l}<.01 \\
0.01\end{array}$ & $\begin{array}{l}5.52 \\
\pm \\
7.64\end{array}$ & $\begin{array}{l}2.50 \\
\frac{ \pm}{3.80}\end{array}$ & $\begin{array}{l}<.01 \\
0.01\end{array}$ & $\begin{array}{l}4.00 \\
\pm \\
6.01\end{array}$ & $\begin{array}{l}2.74 \\
\pm \\
3.57\end{array}$ & 0.471 \\
\hline $\begin{array}{l}\text { DC- } \\
\text { SIGN }\end{array}$ & Immature & $\begin{array}{l}1.88 \pm \\
6.45\end{array}$ & $0 . \pm 0$ & 0.258 & $\begin{array}{l}1.34 \\
\pm \\
5.84\end{array}$ & $\begin{array}{l}0 . \pm \\
0 .\end{array}$ & 0.506 & $\begin{array}{l}0 . \pm \\
0 .\end{array}$ & $\begin{array}{l}0 . \pm \\
0 .\end{array}$ & 0.528 \\
\hline DEC205 & Mature/activated & $\begin{array}{l}0.32 \pm \\
1.90\end{array}$ & $\begin{array}{l}0.66 \pm \\
2.77\end{array}$ & 0.507 & $\begin{array}{l}0.60 \\
\pm \\
2.49\end{array}$ & $\begin{array}{l}0.63 \\
\pm \\
2.25\end{array}$ & 0.531 & $\begin{array}{l}0.38 \\
\pm \\
2.05\end{array}$ & $\begin{array}{l}0.35 \\
\pm \\
1.64\end{array}$ & 0.526 \\
\hline $\begin{array}{l}\text { DC- } \\
\text { LAMP }\end{array}$ & Mature/activated & $\begin{array}{l}1.38 \pm \\
3.21\end{array}$ & $\begin{array}{l}2.38 \pm \\
6.04\end{array}$ & 0.527 & $\begin{array}{l}1.63 \\
\pm \\
4.59\end{array}$ & $\begin{array}{l}0.76 \\
\pm \\
1.65\end{array}$ & 0.527 & $\begin{array}{l}1.79 \\
\pm \\
4.87\end{array}$ & $\begin{array}{l}1.25 \\
\pm \\
2.91\end{array}$ & 0.526 \\
\hline CD123 & Plasmacytoid & $0 . \pm 0$. & $0 . \pm 0$ & 0.527 & $\begin{array}{l}0 . \pm \\
0 .\end{array}$ & $\begin{array}{l}0 . \pm \\
0 .\end{array}$ & 0.532 & $\begin{array}{l}0 . \pm \\
0 .\end{array}$ & $\begin{array}{l}0 . \pm \\
0 .\end{array}$ & 0.528 \\
\hline
\end{tabular}

CD44v9, CD44 variant 9; EpCAM, epithelial cell adhesion molecule; Sox9, sex determining region Y-box9

Expression of mRNA of CSC markers by RT-PCR

Positive mRNA bands for CD44v9 and EpCAM in breast cancer and for Sox 9 in colorectal cancer were confirmed for use as positive controls (Fig. 2). All 4 ICC cases expressed any mRNAs for CD44v9 at 52 bp, for EpCAM at 100 bp, and for Sox9 at 132 bp.

\section{Comparison of PFS and OS between the CD44v9 ${ }^{-}$and CD44v9 ${ }^{+}$groups, the EpCAM ${ }^{\text {low }}$ and EpCAM ${ }^{\text {high }}$ groups, and the Soxglow and Sox $9^{\text {high }}$ groups}

Comparison between the CD44v9 $9^{+}$and $C D 44 v 9^{-}$groups and the EpCAM low and EpCAM ${ }^{\text {high }}$ groups by the Kaplan-Meier method (log-rank test) showed no significant difference in PFS $(P=0.437)$ and OS $(P=0.790)$ (Fig. 3a $\&$ b) or in PFS $(P=0.084)$ and OS $(P=0.095)$ (Fig. 3c \& d), respectively. However, the Sox9low group had significantly shorter PFS $(P=0.029)$ and $0 S(P=0.012)$ than the Soxghigh group (Fig. $3 e \& f$ ).

\section{Univariate And Multivariate Analyses For Clinicopathological Factors}

There were no significant associations between any clinicopathological factors and OS in either the univariate or multivariate analysis (Table 3). On the other hand, only Sox9 among the clinicopathological factors in both the univariate and multivariate analyses was significantly associated with PFS ( $P=0.016$ and 0.025 , respectively) (Table 4). 
Table 3

Results of univariate and multivariate analyses for overall survival $(n=20)$

\begin{tabular}{|c|c|c|c|c|c|c|c|c|}
\hline \multicolumn{2}{|c|}{ Clinicopathological factor } & \multirow[t]{2}{*}{$\mathrm{n}$} & \multicolumn{3}{|c|}{ Univariate analysis } & \multicolumn{3}{|c|}{ Multivariate analysis } \\
\hline & & & $\begin{array}{l}\text { Hazard } \\
\text { ratio }\end{array}$ & $95 \% \mathrm{Cl}$ & $\begin{array}{l}P \\
\text { value }\end{array}$ & $\begin{array}{l}\text { Hazard } \\
\text { ratio }\end{array}$ & $95 \% \mathrm{Cl}$ & $\begin{array}{l}P \\
\text { value }\end{array}$ \\
\hline \multirow[t]{2}{*}{ Age (years) } & $<68$ & 8 & 1.243 & $\begin{array}{l}0.242- \\
5.427\end{array}$ & 0.779 & & & \\
\hline & $\geqq 68$ & 12 & - & - & - & & & \\
\hline \multirow[t]{2}{*}{ Gender } & Male & 16 & 866585356 & $\begin{array}{l}1.297- \\
1.297\end{array}$ & NA & & & \\
\hline & Female & 4 & - & - & - & & & \\
\hline \multirow[t]{2}{*}{ Tumor size } & $<30 \mathrm{~mm}$ & 10 & 1.470 & $\begin{array}{l}0.322- \\
7.504\end{array}$ & 0.614 & & & \\
\hline & $\geqq$ & 9 & - & - & - & & & \\
\hline \multirow[t]{2}{*}{ Histology } & Mod/Por & 12 & 3.264 & $\begin{array}{l}0.740- \\
22.481\end{array}$ & 0.122 & 1.337 & $\begin{array}{l}0.107- \\
20.332\end{array}$ & 0.817 \\
\hline & Wel & 8 & - & - & - & & & \\
\hline \multirow[t]{2}{*}{ pT } & $1+2$ & 19 & 209131479 & $\begin{array}{l}0.302- \\
0.302\end{array}$ & NA & & & \\
\hline & $3+4$ & 1 & - & - & - & & & \\
\hline \multirow[t]{2}{*}{$\begin{array}{l}\text { Lymph node } \\
\text { metastasis }\end{array}$} & Positive & 7 & 2.156 & $\begin{array}{l}0.474- \\
10.973\end{array}$ & 0.313 & 1.897 & $\begin{array}{l}0.110- \\
32.569\end{array}$ & 0.644 \\
\hline & Negative & 13 & - & - & - & & & \\
\hline \multirow[t]{2}{*}{ Stage } & IIIIIV & 8 & 1.507 & $\begin{array}{l}0.330- \\
7.692\end{array}$ & 0.590 & & & \\
\hline & Ill| & 12 & - & - & - & & & \\
\hline \multirow[t]{2}{*}{ Vascular invasion } & Positive & 5 & 1.889 & $\begin{array}{l}0.362- \\
8.776\end{array}$ & 0.424 & & & \\
\hline & Negative & 13 & - & - & - & & & \\
\hline \multirow[t]{2}{*}{ CD1a (/HPF) } & $<5$ & 11 & 3.870 & $\begin{array}{l}0.654- \\
73.368\end{array}$ & 0.149 & 2.556 & $\begin{array}{l}0.159- \\
73.405\end{array}$ & 0.502 \\
\hline & $\geqq 5$ & 9 & - & - & - & & & \\
\hline \multirow[t]{2}{*}{ CD44v9 } & High & 12 & 0.828 & $\begin{array}{l}0.195- \\
3.515\end{array}$ & 0.790 & 0.829 & $\begin{array}{l}0.065- \\
9.825\end{array}$ & 0.877 \\
\hline & Low & 8 & - & - & - & & & \\
\hline \multirow[t]{2}{*}{ ЕрСАM } & High & 16 & 0.291 & $\begin{array}{l}0.064- \\
1.494\end{array}$ & 0.129 & 0.387 & $\begin{array}{l}0.033- \\
4.250\end{array}$ & 0.419 \\
\hline & Low & 4 & - & - & - & & & \\
\hline Sox9 & High & 14 & $2.348^{e-10}$ & $\begin{array}{l}0.207- \\
0.207\end{array}$ & NA & $\begin{array}{l}1.179^{e-} \\
10\end{array}$ & $\begin{array}{l}4.42^{e-19} \\
0.339\end{array}$ & NA \\
\hline
\end{tabular}

$\mathrm{Cl}$, confidence interval; HPF, high power field; NA, not available; Mod, moderately differentiated; Por, poorly differentiated; CD44v9, CD44 variant 9; EpCAM, epithelial cell adhesion molecule; Sox9, sex determining region Y-box9 


\begin{tabular}{|c|c|c|c|c|c|c|c|}
\hline \multirow[t]{2}{*}{ Clinicopathological factor } & \multirow[t]{2}{*}{$\mathbf{n}$} & \multicolumn{3}{|c|}{ Univariate analysis } & \multicolumn{3}{|c|}{ Multivariate analysis } \\
\hline & & $\begin{array}{l}\text { Hazard } \\
\text { ratio }\end{array}$ & $95 \% \mathrm{Cl}$ & $\begin{array}{l}P \\
\text { value }\end{array}$ & $\begin{array}{l}\text { Hazard } \\
\text { ratio }\end{array}$ & $95 \% \mathrm{Cl}$ & $\begin{array}{l}P \\
\text { value }\end{array}$ \\
\hline Low & 6 & - & - & - & & & \\
\hline
\end{tabular}


Table 4

Results of univariate analysis for progression-free survival $(n=20)$

\begin{tabular}{|c|c|c|c|c|c|c|c|c|}
\hline \multicolumn{2}{|c|}{ Clinicopathological factor } & \multirow[t]{2}{*}{$\mathbf{n}$} & \multicolumn{3}{|c|}{ Univariate analysis } & \multicolumn{3}{|c|}{ Multivariate analysis } \\
\hline & & & $\begin{array}{l}\text { Hazard } \\
\text { ratio }\end{array}$ & $95 \% \mathrm{Cl}$ & $\begin{array}{l}P \\
\text { value }\end{array}$ & $\begin{array}{l}\text { Hazard } \\
\text { ratio }\end{array}$ & $95 \% \mathrm{Cl}$ & $\begin{array}{l}P \\
\text { value }\end{array}$ \\
\hline \multirow[t]{2}{*}{ Age (years) } & $<68$ & 8 & 0.660 & $\begin{array}{l}0.435- \\
6.937\end{array}$ & 0.531 & & & \\
\hline & $\geqq 68$ & 12 & - & - & - & & & \\
\hline \multirow[t]{2}{*}{ Gender } & Male & 16 & 1.664 & $\begin{array}{l}0.424- \\
10.970\end{array}$ & 0.496 & & & \\
\hline & Female & 4 & - & - & - & & & \\
\hline \multirow[t]{2}{*}{ Tumor size } & $<30 \mathrm{~mm}$ & 10 & 1.243 & $\begin{array}{l}0.372- \\
4.335\end{array}$ & 0.721 & & & \\
\hline & $\geqq$ & 9 & - & - & - & & & \\
\hline \multirow[t]{2}{*}{ Histology } & Mod/Por & 12 & 2.249 & $\begin{array}{l}0.698- \\
8.522\end{array}$ & 0.177 & 1.473 & $\begin{array}{l}0.374- \\
6.721\end{array}$ & 0.583 \\
\hline & Wel & 8 & - & - & - & & & \\
\hline \multirow[t]{2}{*}{ pT } & $1+2$ & 19 & 208470764 & $\begin{array}{l}0.462- \\
0.462\end{array}$ & NA & & & \\
\hline & $3+4$ & 1 & - & - & - & & & \\
\hline \multirow[t]{2}{*}{$\begin{array}{l}\text { Lymph node } \\
\text { metastasis }\end{array}$} & Positive & 7 & 2.870 & $\begin{array}{l}0.860- \\
10.011\end{array}$ & 0.085 & 4.049 & $\begin{array}{l}0.748- \\
26.743\end{array}$ & 0.105 \\
\hline & Negative & 13 & - & - & - & & & \\
\hline \multirow[t]{2}{*}{ Stage } & IIIIIV & 8 & 1.997 & $\begin{array}{l}0.596- \\
6.983\end{array}$ & 0.257 & & & \\
\hline & |미 & 12 & - & - & - & & & \\
\hline \multirow[t]{2}{*}{ Vascular invasion } & Positive & 5 & 1.053 & $\begin{array}{l}0.225- \\
3.759\end{array}$ & 0.941 & & & \\
\hline & Negative & 13 & - & - & - & & & \\
\hline \multirow[t]{2}{*}{ CD1a (/HPF) } & $<5$ & 11 & 1.501 & $\begin{array}{l}0.445- \\
5.803\end{array}$ & 0.516 & 1.313 & $\begin{array}{l}0.288- \\
6.457\end{array}$ & 0.723 \\
\hline & $\geqq 5$ & 9 & - & - & - & & & \\
\hline \multirow[t]{2}{*}{ CD44v9 } & High & 12 & 1.616 & $\begin{array}{l}0.504- \\
6.108\end{array}$ & 0.427 & 0.952 & $\begin{array}{l}0.163- \\
5.859\end{array}$ & 0.956 \\
\hline & Low & 8 & - & - & - & & & \\
\hline \multirow[t]{2}{*}{ ЕрСАM } & High & 16 & 0.317 & $\begin{array}{l}0.089- \\
1.473\end{array}$ & 0.129 & 0.319 & $\begin{array}{l}0.032- \\
3.922\end{array}$ & 0.343 \\
\hline & Low & 4 & - & - & - & & & \\
\hline Sox9 & High & 14 & 0.173 & $\begin{array}{l}0.035- \\
0.718\end{array}$ & 0.016 & 0.129 & $\begin{array}{l}0.016- \\
0.771\end{array}$ & 0.025 \\
\hline
\end{tabular}




\begin{tabular}{|c|c|c|c|c|c|c|c|}
\hline \multirow[t]{2}{*}{ Clinicopathological factor } & \multirow[t]{2}{*}{ n } & \multicolumn{3}{|c|}{ Univariate analysis } & \multicolumn{3}{|c|}{ Multivariate analysis } \\
\hline & & $\begin{array}{l}\text { Hazard } \\
\text { ratio }\end{array}$ & $95 \% \mathrm{Cl}$ & $\begin{array}{l}P \\
\text { value }\end{array}$ & $\begin{array}{l}\text { Hazard } \\
\text { ratio }\end{array}$ & $95 \% \mathrm{Cl}$ & $\begin{array}{l}P \\
\text { value }\end{array}$ \\
\hline Low & 6 & - & - & - & & & \\
\hline
\end{tabular}

\section{Discussion}

In the present study, $\mathrm{CD} 1 \mathrm{a}^{+}$immature DCs were the most numerous among DCs at various maturation stages infiltrating ICC tumour nests (Table 1). Other DCs, including DC-SIGN ${ }^{+}, D^{2}$ EC205 ${ }^{+}$, DC-LAMP ${ }^{+}$, and CD123 ${ }^{+}$DCs, were relatively few. CD1 ${ }^{+}$DCs are immature epithelial-related DCs of the Langerhans cell type, are derived from myeloid progenitor cells, have excellent antigen-capturing ability and are abundant in the epidermis and mucosal epithelium. They frequently infiltrate a variety of cancers originating from epithelial cells, including breast, gastric, pancreatic, laryngeal, and ovarian cancers and also infiltrate non-epithelial cell-derived sarcomas, such as malignant melanoma, and might contribute to the rate of recurrence and metastasis(3) (26). Conversely, DC-SIGN ${ }^{+}$DCs, also known as immature DCs, infiltrate the interstitium while adhering to hyaluronic acid as stroma-related DCs but hardly infiltrate the epithelium, epidermis, and cancer nests. Therefore, as indicated in the present study, CD1a+ DCs are likely to infiltrate ICC tumour nests and have a high chance of directly capturing antigens from ICC tumour cells.

No previous reports have examined the histopathological relationship between CSCs and infiltrating DCs in ICC. CD133(8), CD44(9), EpCAM(10), ALDH1(11), Sox2(9), and Sox9(12) have already been reported as CSC markers for ICC. For the first time, we demonstrated that the frequency of $\mathrm{CD} 1 \mathrm{a}^{+}$immature DCs was significantly higher in the CD44v9- group than in the CD44v9+ group and in the EpCAM ${ }^{\text {high }}$ group than in the EpCAM ${ }^{\text {low }}$ group (Table 2). The mRNA expression of any CSC marker was confirmed by RT-PCR (Fig. 3). CD44v9 interacts with the first apoptosis signal (Fas) and suppresses apoptosis of tumour cells(27), suggesting that CD44v9-positive CSCs may hardly cause apoptosis, so very few tumour antigens may be released. Even if CD1a+ DCs infiltrate the CSC nests, few antigens may be captured. Conversely, it may be possible that CD1a ${ }^{+}$DCs infiltrate CD44v9-negative tumour nests relatively easily, as shown in this study, and thus easily capture tumour antigens. EpCAM is a $40 \mathrm{kD}$ glycoprotein and a homophilic cell-cell adhesion molecule(28). Epithelial cells overexpressing EpCAM are able to downregulate E-cadherin, and increasing expression of EPCAM in cadherin-positive cells leads to the gradual abrogation of adhere junctions(29). Therefore, it may be possible that CD1a+ DCs may infiltrate tumour nests more easily because the adhesion ability between tumour cells may be weaker in EpCAM-overexpressing tumours.

The $\mathrm{CD} 44 \mathrm{v} 9^{+}$group had a poor prognosis for hepatocellular carcinoma, breast cancer, plasmacytoma, gastric cancer, bladder cancer, gallbladder cancer and ICC (15, 21, 30-33). There was, however, no significant difference in the PFS and OS between the CD44v9+ and CD44v9- groups by the Kaplan-Meier method (log-rank test) and Cox proportional hazards model in the present study (Tables 3 \& 4, Fig. 3). The amount of EpCAM expression on ICC tumour cells was also not associated with survival in the Cox proportional hazards model. It is suggested that one reason for this is because the number of cases may be small in this study. The Sox $9^{\text {low }}$ group had significantly shorter PFS and OS than the Sox ${ }^{\text {high }}$ group. Sox9 plays an important role in the embryonic formation of several tissues and organs, such as the testis, heart, lung, pancreas, biliary tract, and central nervous system(18). Although Sox9-highly expressed ICC is considered to have a poor prognosis(12), it has also been reported that Sox9 is independent of tumour differentiation in biliary tract cancers, including extrahepatic cholangiocarcinoma, and OS is shortened in patients without positive cytoplasmic expression(34). The latter report suggests that Sox9 is involved in the differentiation of bile duct epithelium, and its loss of expression causes malignant transformation. The present study demonstrated that Sox9negative cases had no nuclear expression, but negative cases had poor prognosis, as shown by both univariate and multivariate analyses of the Cox proportional hazards model between the Sox $9^{\text {high }}$ and Sox ${ }^{\text {low }}$ groups. 


\section{Conclusion}

The present study first demonstrated that epithelial type CD1a+ immature DCs frequently infiltrated CD44v9- and EpCAM ${ }^{\text {high }}$ ICC tumour nests, suggesting the possibility of cell-to-cell contact between this type of DC and CSCs in ICC. Furthermore, the present study also suggested that the frequent expression of Sox9 in ICC may be an independent prognostic factor.

\section{Abbreviations}

CD44v9: CD44 variant 9; CSC: cancer stem cell; EpCAM: epithelial cell adhesion molecule; ICC: intrahepatic cholangiocarcinoma; OS: overall survival; PBS: phosphate buffered saline; PFS: progression-free survival; RT-PCR: reverse transcription-polymerase chain reaction; Sox9: sex determining region Y-box9

\section{Declarations}

Availability of data and materials

Is available upon request from the corresponding author.

Ethics approval and consent to participate

This study was approved by the Yamagata University School of Medicine Ethics Committee (H29-302).

Consent for publication

Not applicable.

\section{Conflict of interest}

All authors declare no conflict of interest.

\section{Funding}

This work was supported by a Grant-in-Aid for Scientific Research (C) (JP17K08736) and a Grant-in-Aid for Young Scientists (JP19K16577) of Japan Society for the Promotion of Science.

\section{Authors'contributions}

All authors made substantial contributions to the paper. U.A. evaluated andscored every immunohistochemical staining slide and wrote the manuscript. U.A. and K.T. counted a number of DCs positive for each DC marker. O.R. wrote and edited the manuscript. U.Y. collected the clinical data. All authors read and approved the final version of the manuscript. 
This work was supported by a Grant-in-Aid for Scientific Research (C) (JP17K08736) and a Grant-in-Aid for Young Scientists (JP19K16577) of Japan Society for the Promotion of Science. The author is grateful to Hiromi Murata, Junko Takeda, Kumiko Abe, and Hitoshi Suzuki (Department of Pathological Diagnostics, Yamagata University Faculty of Medicine) and Ayumi Suzuki, Ami Shida, Teppei Shiraiwa, Tomonori Saito, and Toshinori Suzuki (Division of Clinical Laboratory, Yamagata University Hospital) for their valuable assistance during this study.

\section{References}

1. Liu K, Nussenzweig MC. Dendritic Cells. In: Paul WE, editor. Fundamental Immunology, 7th Edition. seventh edition ed. Philadelphia: Lippincott Williams \& Wilkins (LWW); 2013. p. 381-394.

2. Gardner A, Ruffell B. Dendritic Cells and Cancer Immunity. Trends Immunol. 2016;37(12):855-65.

3. Tsuge K, Takeda H, Kawada S, Maeda K, Yamakawa M. Characterization of dendritic cells in differentiated thyroid cancer. J Pathol. 2005;205(5):565-76.

4. Mitsui $H$, Ohtake $H$, Ohe R, Yamakawa M. Frequent infiltration of S-100 protein + CCR5 + immature dendritic cells in damaged bile ducts of primary biliary cirrhosis compared to cholangiocellular carcinoma. Pathology and Laboratory Medicine International. 2013.

5. Chen Z, Guo P, Xie X, Yu H, Wang Y, Chen G. The role of tumour microenvironment: a new vision for cholangiocarcinoma. J Cell Mol Med. 2019;23(1):59-69.

6. Zhu CP, Wang AQ, Zhang HH, Wan XS, Yang XB, Chen SG, et al. Research progress and prospects of markers for liver cancer stem cells. World J Gastroenterol. 2015;21(42):12190-6.

7. Wu HJ, Chu PY. Role of Cancer Stem Cells in Cholangiocarcinoma and Therapeutic Implications. Int J Mol Sci. 2019;20(17).

8. Leelawat K, Thongtawee T, Narong S, Subwongcharoen S, Treepongkaruna SA. Strong expression of CD133 is associated with increased cholangiocarcinoma progression. World J Gastroenterol. 2011;17(9):1192-8.

9. Gu MJ, Jang BI. Clinicopathologic significance of Sox2, CD44 and CD44v6 expression in intrahepatic cholangiocarcinoma. Pathol Oncol Res. 2014;20(3):655-60.

10. Cardinale V, Renzi A, Carpino G, Torrice A, Bragazzi MC, Giuliante F, et al. Profiles of cancer stem cell subpopulations in cholangiocarcinomas. Am J Pathol. 2015;185(6):1724-39.

11. Wang M, Xiao J, Jiang J, Qin R. CD133 and ALDH may be the molecular markers of cholangiocarcinoma stem cells. Int J Cancer. 2011;128(8):1996-7.

12. Yuan X, Li J, Coulouarn C, Lin T, Sulpice L, Bergeat D, et al. SOX9 expression decreases survival of patients with intrahepatic cholangiocarcinoma by conferring chemoresistance. Br J Cancer. 2018.

13. Senbanjo LT, Chellaiah MA. CD44: A Multifunctional Cell Surface Adhesion Receptor Is a Regulator of Progression and Metastasis of Cancer Cells. Front Cell Dev Biol. 2017;5:18.

14. Thapa R, Wilson GD. The Importance of CD44 as a Stem Cell Biomarker and Therapeutic Target in Cancer. Stem Cells Int. 2016;2016:2087204.

15. Kakehashi A, Ishii N, Sugihara E, Gi M, Saya H, Wanibuchi H. CD44 variant 9 is a potential biomarker of tumor initiating cells predicting survival outcome in hepatitis $\mathrm{C}$ virus-positive patients with resected hepatocellular carcinoma. Cancer Sci. 2016;107(5):609-18.

16. Cardinale V, Wang Y, Carpino G, Cui CB, Gatto M, Rossi M, et al. Multipotent stem/progenitor cells in human biliary tree give rise to hepatocytes, cholangiocytes, and pancreatic islets. Hepatology. 2011;54(6):2159-72.

17. Sulpice L, Rayar M, Turlin B, Boucher E, Bellaud $P$, Desille $M$, et al. Epithelial cell adhesion molecule is a prognosis marker for intrahepatic cholangiocarcinoma. J Surg Res. 2014;192(1):117-23.

18. Matsushima H, Kuroki T, Kitasato A, Adachi T, Tanaka T, Hirabaru M, et al. Sox9 expression in carcinogenesis and its clinical significance in intrahepatic cholangiocarcinoma. Dig Liver Dis. 2015;47(12):1067-75.

19. Huang L, Cai J, Guo H, Gu J, Tong Y, Qiu B, et al. ID3 Promotes Stem Cell Features and Predicts Chemotherapeutic Response of Intrahepatic Cholangiocarcinoma. Hepatology. 2019;69(5):1995-2012. 
20. Nakamura Y, Curado M-P, Franceschi S, Gores G, Paradis V, Sripa B. Intrahepatic cholangiocarcinoma. In: Bosman FT, Carneiro F, Hruban RH, Theise ND, editors. WHO Classification of Tumours of the Digestive Systems. 4th edition ed. Lyon: International Agency for Research on Cancer (IARC); 2010. p. 217-224.

21. Tokunaga E, Fujita A, Takizawa K, Baba K, Akiyoshi S, Nakamura Y, et al. CD44v9 as a poor prognostic factor of triplenegative breast cancer treated with neoadjuvant chemotherapy. Breast Cancer. 2018.

22. Sadeghi S, Hojati Z, Tabatabaeian H. Cooverexpression of EpCAM and c-myc genes in malignant breast tumours. J Genet. 2017;96(1):109-18.

23. Marcker Espersen ML, Linnemann D, Christensen IJ, Alamili M, Troelsen JT, Hogdall E. SOX9 expression predicts relapse of stage II colon cancer patients. Hum Pathol. 2016;52:38-46.

24. Ohe R, Aung NY, Shiono Y, Utsunomiya A, Kabasawa T, Tamazawa N, et al. Detection of Minimal Bone Marrow involvement of Blastic Plasmacytoid Dendritic Cell Neoplastic Cells - CD303 immunostaining as a diagnostic tool. J Clin Exp Hematop. 2018;58(1):1-9.

25. Aung NY, Ohe R, Meng H, Kabasawa T, Yang S, Kato T, et al. Specific Neuropilins Expression in Alveolar Macrophages among Tissue-Specific Macrophages. PLoS One. 2016;11(2):e0147358.

26. Jardim JF, Gondak R, Galvis MM, Pinto CAL, Kowalski LP. A decreased peritumoral CD1a + cell number predicts a worse prognosis in oral squamous cell carcinoma. Histopathology. 2018;72(6):905-13.

27. Nagano 0 , Okazaki S, Saya H. Redox regulation in stem-like cancer cells by CD44 variant isoforms. Oncogene. 2013;32(44):5191-8.

28. de Boer CJ, van Krieken JH, Janssen-van Rhijn CM, Litvinov SV. Expression of Ep-CAM in normal, regenerating, metaplastic, and neoplastic liver. J Pathol. 1999;188(2):201-6.

29. Gaiser MR, Lämmermann T, Feng X, Igyarto BZ, Kaplan DH, Tessarollo L, et al. Cancer-associated epithelial cell adhesion molecule (EpCAM; CD326) enables epidermal Langerhans cell motility and migration in vivo. Proc Natl Acad Sci USA. 2012;109(15):E889-97.

30. Stauder R, Van Driel M, Schwarzler C, Thaler J, Lokhorst HM, Kreuser ED, et al. Different CD44 splicing patterns define prognostic subgroups in multiple myeloma. Blood. 1996;88(8):3101-8.

31. Hirata K, Suzuki H, Imaeda H, Matsuzaki J, Tsugawa H, Nagano O, et al. CD44 variant 9 expression in primary early gastric cancer as a predictive marker for recurrence. $\mathrm{Br} J$ Cancer. 2013;109(2):379-86.

32. Kobayashi K, Matsumoto H, Matsuyama H, Fujii N, Inoue R, Yamamoto Y, et al. Clinical significance of CD44 variant 9 expression as a prognostic indicator in bladder cancer. Oncol Rep. 2016;36(5):2852-60.

33. Miwa T, Nagata T, Kojima H, Sekine S, Okumura T. Isoform switch of CD44 induces different chemotactic and tumorigenic ability in gallbladder cancer. Int J Oncol. 2017;51(3):771-80.

34. Demarez C, Hubert C, Sempoux C, Lemaigre FP. Expression of Molecular Differentiation Markers Does Not Correlate with Histological Differentiation Grade in Intrahepatic Cholangiocarcinoma. PLoS One. 2016;11(6):e0157140.

\section{Figures}



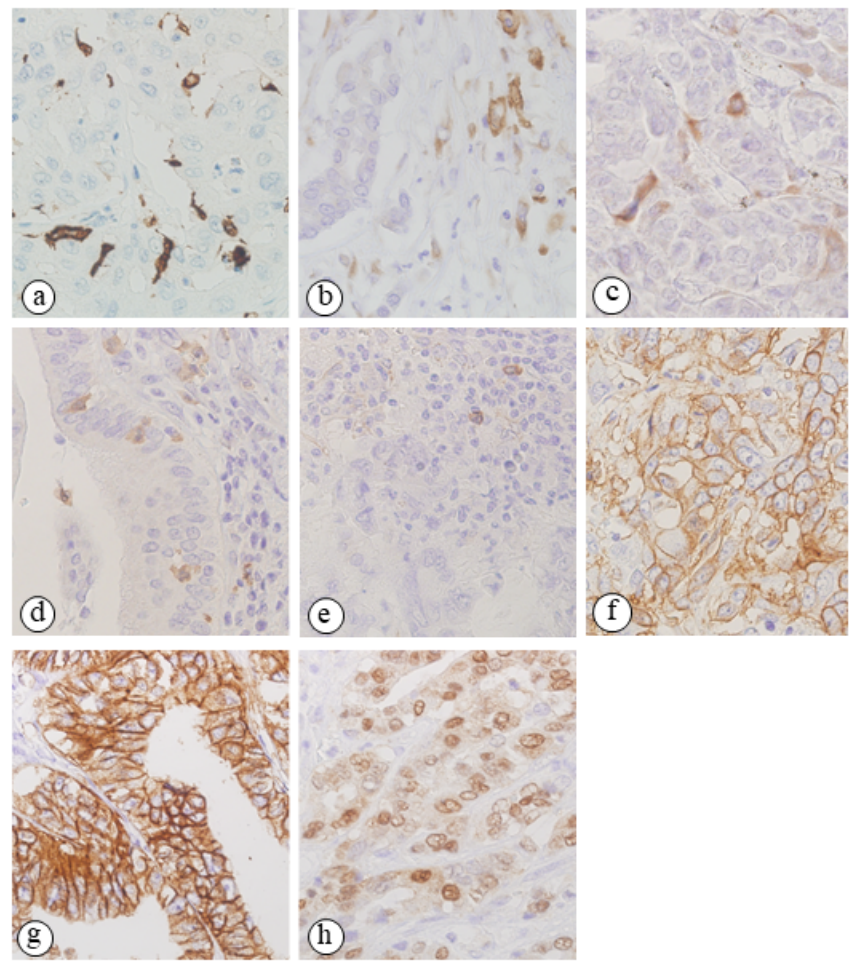

Figure 1

Figure 1

Subtype of dendritic cells (DCs) infiltrating tumour nests and expression of cancer stem cell markers on tumour cells in ICC. Immunostaining of CD1a (1a), DC-SIGN (1b), DEC205 (1c), DC-LAMP (1d), and CD123 (1e). Note that many more CD1a+ DCs infiltrate tumour nests than other types of DCs. Membrane CD44 variant 9 (CD44v9) (1f), epithelial cell adhesion molecule (EрCAM) (1g), and nuclear sex determining region Y-box9 (Sox9) (1h) are expressed on the majority of tumour cells in these tumour nests. 


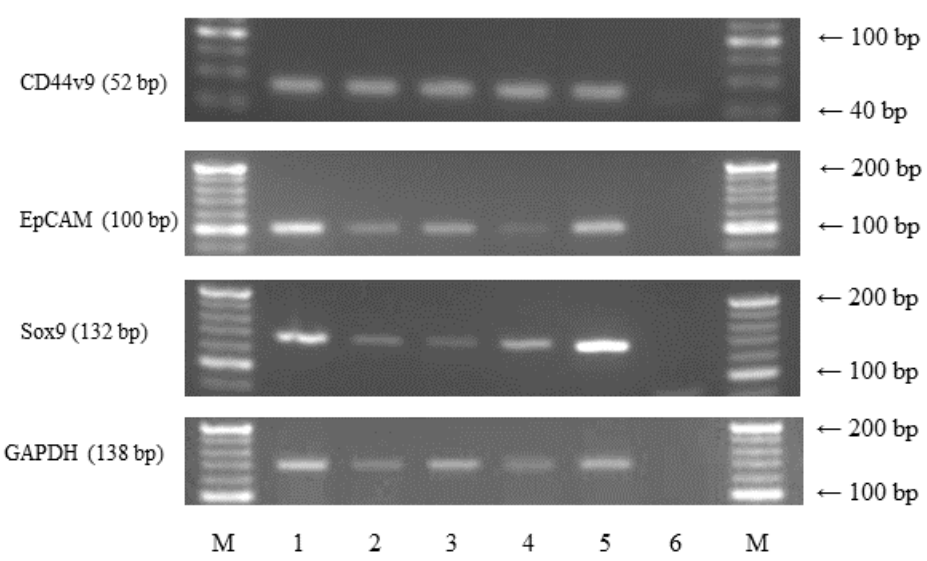

Figure 2

Figure 2

RT-PCR of mRNAs of cancer stem cell markers in ICC. The mRNAs of CD44v9 and EpCAM in breast cancer and Sox9 in colon cancer used as controls are expressed in lane 5 . In all 4 cases of ICC, any mRNAs of CD44V9, EpCAM, and Sox 9 were expressed. Lanes 1-4: ICC, lane 5; positive control, lane 6; negative control, M; ladder marker. CD44v9, CD44 variant 9; EpCAM, epithelial cell adhesion molecule; Sox9, sex determining region Y-box9; GAPDH, glyceraldehyde-3-phosphate dehydrogenase. 
(a)

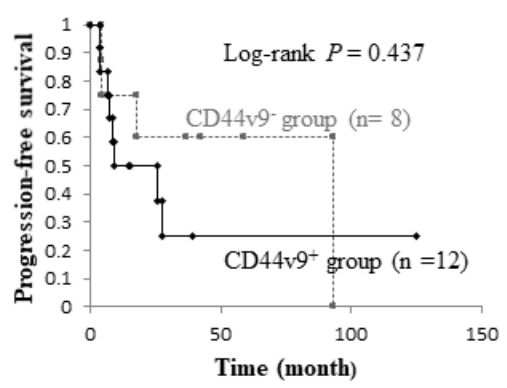

(c)

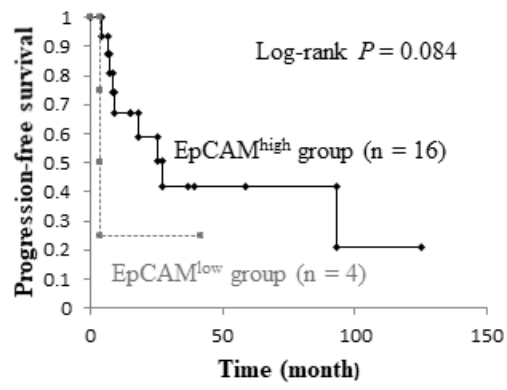

(e)

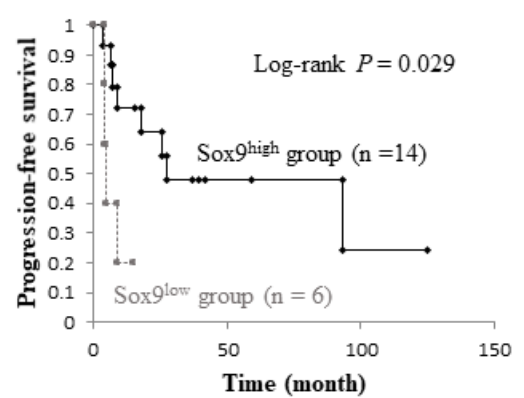

(b)

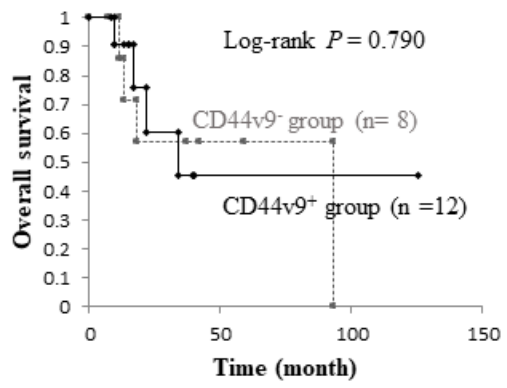

(d)

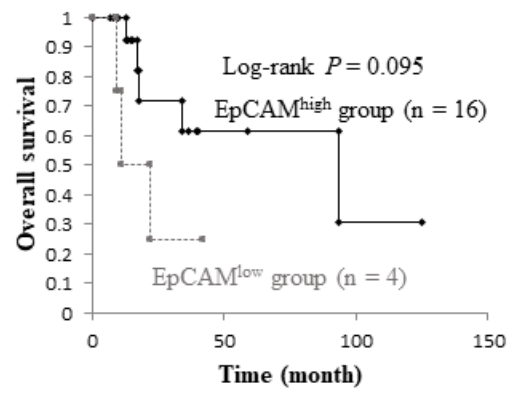

(f)

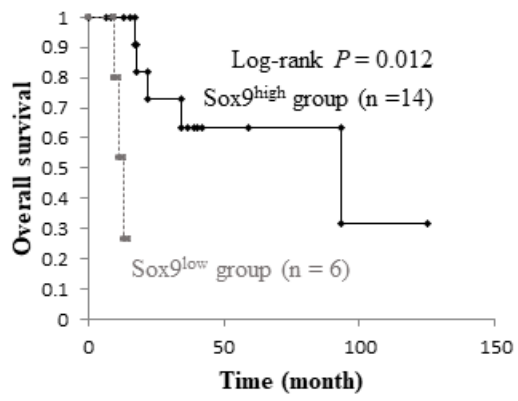

Figure 3

Figure 3

Relationship between the frequency of cancer stem cell marker expression and Kaplan-Meier curve in ICC. There was no significant difference in the PFS $(P=0.314)$ or OS $(P=0.751)$ between the CD44v9- and CD44v9+ groups $(3 a$ \& $3 b)$ or in the PFS $(P=0.107)$ or OS $(P=0.219)$ between the EpCAMhigh and EpCAMlow groups of ICC ( $3 c \& 3 d)$. However, both the $P F S(P=$ $0.032)$ and OS $(P=0.002)$ were significantly shorter in the Sox9low group than in the Sox9high group of ICC (3e \& 3f). CD44v9, CD44 variant 9; EpCAM, epithelial cell adhesion molecule; Sox9, sex determining region Y-box9.

\section{Supplementary Files}

This is a list of supplementary files associated with this preprint. Click to download.

- Supplementfigure.pptx 